\title{
Pengaruh Gaya Kepemimpinan dan Motivasi pada Komitmen Organisasi dengan Kepuasan Kerja Sebagai Variabel Intervensi Anggota Batalyon A Brimob Mabes Sulut
}

\author{
Hendrikson R. Wowiling ${ }^{1}$, Benhard Tewal ${ }^{2}$, Rudy S. Wenas ${ }^{2}$ \\ ${ }^{1}$ Mahasiswa Progam Studi Magister Manajemen Fakultas Ekonomi Dan Bisnis \\ ${ }^{2}$ Progam Studi Magister Manajemen Fakultas Ekonomi Dan Bisnis \\ Universitas Sam Ratulangi, Manado \\ Universitas Sam Ratulangi, Manado \\ Email Korespondensi: hendriksonwowiling@yahoo.com
}

Received: 04 Januari 2021; Revised: 26 Februari 2021; Accepted: 28 April 2021

DOI: http://dx.doi.org/10.37905/aksara.7.2.647-658.2021

\begin{abstract}
Abstrak
Jenis penelitian ini adalah penelitian yang dilakukan dengan menggunakan metode Regresi Linier Berganda untuk menjelaskan hubungan langsung dan tidak langsung serta faktor psikologis secara simultan dan parsial dari variabel Gaya Kepemimpinan, Motivasi, Kepuasan Kerja, dan Komitmen Organisasi pada Anggota Brimob Polri. Kantor Pusat Sulawesi Utara. Objek penelitian yang dipilih adalah Batalyon "A" Divisi Brimob dengan sampel sebanyak 136 responden. Teknik analisis data dengan bantuan software SPSS v.24.0 untuk Windows. Hasil penelitian menunjukkan bahwa pengaruh langsung Gaya Kepemimpinan (X1) dan Kepuasan Kerja (Y) secara simultan berpengaruh signifikan dan positif terhadap Komitmen Organisasi (Z), sedangkan Motivasi (X2) berpengaruh positif dan signifikan terhadap Komitmen Organisasi (Z).

Kata Kunci: Gaya Kepemimpinan, Motivasi, Kepuasan Kerja, Keyakinan, dan Komitmen Organisasi
\end{abstract}

\footnotetext{
Abstract

This type of research is a research conducted using the Multiple Linear Regression method to explain the direct and indirect relationships as well as psychological factors simultaneously and partially from the variables of Leadership Style, Motivation, Job Satisfaction, and Organizational Commitment of Brimob Polri Members. North Sulawesi Head Office. The research object chosen was Battalion "A" Brimob Division with a sample of 136 respondents. Data analysis techniques with the help of SPSS v.24.0 software for Windows. The results showed that the direct influence of Leadership Style (X1) and Job Satisfaction (Y) simultaneously had a significant and positive effect on Organizational Commitment (Z), while Motivation (X2) had a positive and significant effect on Organizational Commitment $(Z)$.

Keywords: Leadership Style, Motivation, Job Satisfaction, Confidence, and Organizational Commitment
} 


\section{PENDAHULUAN}

Pengukuran suatu organisasi yang didasarkan pada komitmen organisasi yang sesuai dengan rencana yang ditetapkan. Pencapaian komitmen organisasi menunjukkan bahwa sistem manajemen organisasi berjalan dengan baik sehingga meningkatkan kepercayaan internal dan eksternal organisasi. Oleh karena itu, Robbin dan Judge (2008) menyatakan bahwa komitmen organisasi adalah suatu kondisi dimana seorang anggota / bawahan memihak pada suatu organisasi dan mempunyai keinginan untuk memberdayakannya dalam organisasi.Gaya kepemimpinan dalam suatu organisasi memiliki peran yang sangat penting dalam menentukan suatu organisasi. Herujito (2005: 7) menyatakan bahwa gaya kepemimpinan merupakan cara yang dicapai seseorang dalam rangka mempraktikkan kepemimpinan. Gaya kepemimpinan adalah perilaku pemimpin terhadap pengikutnya, atau cara pemimpin mempengaruhi pengikutnya. Gibson (2006: 8) menyatakan bahwa gaya kepemimpinan merupakan suatu upaya pengaruh tetapi tidak dalam bentuk paksaan (concorsive) untuk memotivasi pekerjaan orang lain untuk mencapai tujuan tertentu. Menurut Oemar Hamalik (2007: 175) motivasi sebagai penggerak, penggerak dan penggerak seseorang untuk mencapai tujuan pribadi dan organisasi. Jadi motivasi adalah berbicara tentang segala sesuatu yang membangkitkan gairah, keinginan, dan energi dari diri sendiri seseorang yang mempengaruhi dan mengarahkan serta menulis perilakunya untuk mencapai tujuan yang diinginkan, sesuai dengan ruang lingkup pekerjaannya. Indy Dan Handoyo (2013) pernyataan bahwa motivasi merupakan salah satu alat untuk insentif dalam bekerja. Kepuasan kerja dalam suatu organisasi merupakan prinsip dasar suatu organisasi dalam mencapai tujuan dan sasaran organisasi. Kepuasan kerja yang rendah akan berimplikasi pada komitmen organisasi. Hal ini disebabkan kepuasan kerja dan komitmen organisasi sangat erat hubungannyanya dan orang yang relatif puas dengan pekerjaannya akan lebih berkomitmen pada organisasi (Mathis dan Jackson, 2011). Berdasarkan latar belakang yang telah diuraikan diatas maka peneliti tertarik untuk melakukan penelitian dengan judul “ Pengaruh Gaya Kepemimpinan dan Motivasi terhadap Komitmen Organisasi dengan Kepuasan Kerja sebagai Variabel Intervensi pada Anggota Batalyon A Divisi Brimob Mabes Polri."

\section{METODE PENELITIAN}

Penelitian ini menggunakan metode penelitian kuantitatif yang menekankan pada analisis data numerik (bilangan) yang diolah dengan metode statistik. Penelitian kuantitatif bekerja dengan angka, yang datanya berupa angka (skor atau nilai, perangkat, atau frekuensi), dianalisis menggunakan statistik untuk menjawab pertanyaan atau hipotesis penelitian yang memprediksi dan memprediksi variabel lain. Dengan kata lain penelitian ini merupakan penelitian asosiatif yang bertujuan untuk melihat pengaruh atau hubungan antara variabel doa atau lebih. Penelitian ini dapat membangun teori yang dapat berfungsi untuk menjelaskan, memprediksi dan mengendalikan suatu gejala dan dapat dilakukan untuk menguji hipotesis dengan statistik inferensial (muncul dan regresi). 
2.1 Teknik Pengumpulan Data

Ada dua metode analisis data yang dilakukan penelitian ini dimana semua data yang dikumpulkan

a. Penelitian lapangan (metode penelitian lapangan) yaitu dengan kuesioner kepada seluruh responden yang menjadi objek penelitian.

b. Pengumpulan data juga dilakukan dengan metode studi pustaka, yaitu studi data dengan melakukan studi terhadap buku, catatan, catatan, dan laporan yang ada catatannya dengan masalah yang sedang dipecahkan.

Berdasarkan jumlah anggota Batalyon A Pelopor sebanyak 236 personel, maka untuk menentukan sampel penelitian ini yang dapat mewakili populasi adalah dengan menggunakan rumus Slovin:

$\mathrm{n}=\frac{\mathrm{N}}{1+\mathrm{N}(\mathrm{e})^{2}}$

Ucapan:

n: jumlah sampel

$\mathrm{N}$ : total populasi

e: Toleransi $1(5 \%$ atau 0,05$)$.

Hasil sampel:

$$
\mathrm{n}=\frac{206}{1+206(0,05)^{2}}=135,97 \text { atau } 136 \text { Responden }
$$

\section{HASIL DAN PEMBAHASAN \\ Uji validitas}

Uji validitas digunakan untuk mengukur validitas suatu kuesioner. Suatu kuesioner valid jika pertanyaan kuesioner dapat mengungkapkan sesuatu yang akan diukur kuesioner tersebut. Uji validitas dihitung dengan membandingkan nilai $r$ hitung (menonton total item) dengan nilai $r$ tabel. Jika $r$ hitung $>r$ tabel dan nilai positif, maka butir atau pertanyaan tersebut dinyatakan valid (Ghozali, 2005: 45).Dalam penelitian ini uji validitas dilakukan dengan menggunakan program SPSS 24.

\section{Tes kepercayaan}

Reliabilitas adalah sejauh mana hasil pengukuran tidak dapat dipercaya. Uji reliabilitas adalah data untuk mengukur suatu kuesioner yang berupa indikator variabel atau konstruk. Kuesioner dapat diandalkan atau dapat diandalkan jika jawaban seseorang atas pernyataan konsisten atau stabil dari waktu ke waktu. Reliabilitas berulang kali konsistensi jawaban jika diuji kali pada sampel yang berbeda. SPSS menyediakan fasilitas untuk mengukur reliabilitas dengan uji statistik Cronbach Alpha $(\alpha)$. Variabel konstruktor reliabel jika memberikan nilai Cronbach Alpha> 0,60 (Ghozali, 2005: 41-42). Reliabilitas dalam penelitian ini dilakukan dengan mengukur jawaban antara jawaban soal menggunakan SPSS 24, dengan uji statistik Cronbach alpha $(\alpha)$. 


\section{Analisis Regresi Linear Berganda}

Teknik analisis data adalah teknik analisis regresi linier berganda. Metode ini digunakan karena dapat menguji satu sampai sembilan variabel.Dalam analisis ini dapat dilihat bagaimana variabel independen yaitu Gaya Kepemimpinan (X1), Motivasi (X2), Kepuasan Kerja (Y) sebagai variabel intervening, dan Komitmen Organisasi (Z) mempengaruhi variabel secara positif maupun negatif) terhadap Anggota Brimob Divisi Batalyon A Mabes Polri. Selanjutnya dalam penelitian ini dilakukan uji Sobet untuk digunakan untuk menguji Hipotesis 6 dan Hipotesis 7. Pengujian mediasi dapat dilakukan dengan menggunakan metode produk koefisien yang dikembangkan oleh Sobel (1982). Uji Sobel dilakukan dengan uji kekuatan pengaruh tidak langsung variabel independen $(X)$ terhadap variabel dependen $(Z)$ variabel intervening (Y). Nilai a dan b merupakan nilai Beta pada kolom Unstandardized Coefficients, maka koefisien kesalahan standar a dan b dituliskan sebagai $\mathrm{Sa}$ dan $\mathrm{Sb}$,

$$
\mathrm{Sab}=\sqrt{b a^{2} S a^{2}+a^{2} S b^{2}+S a^{2} S b^{2}}
$$

Adapun nilai t-statistik dari koefisien ab dapat dihitung dengan rumus sebagai berikut:t $=\frac{a b}{S a b}$

Pengujian hipotesis pertama hingga ketujuh untuk menentukan tingkat signifikansi dengan uji simultan (uji F dan R2) dan uji parsial (uji t) sebagai berikut:

\section{Uji Determinasi (R2)}

Uji determinasi digunakan untuk mengukur sejauh mana model kemampuan dalam menjelaskan variasi variabel dependen. Koefisien determinasi berada di antara nol dan satu. Nilai yang berhenti satu berarti variabel menyediakan hampir semua informasi yang dibutuhkan untuk memprediksi variasi variabel dependen.

\section{Uji F}

Uji F untuk menguji pengaruh secara simultan variabel gaya kepemimpinan, motivasi, dan kepuasan kerja terhadap komitmen organisasi pada anggota Batalyon A Divisi Brimob Mabes Sulut. Pedoman yang digunakan untuk menerima tidak menolak adalah:

- Ha diterima jika F-hitung> F-tabel atau nilai-p pada kolom sig. $<$ tingkat signifikan $(\alpha)$ 5\% artinya semua variabel independen secara bersama-sama mempengaruhi variabel dependen.

- H0 diterima jika F-hitung <F-tabel atau p-value pada kolom sig.> Tingkat signifikansi $(\alpha) \quad 5 \%$ artinya semua variabel tidak berpengaruh secara bersama-sama terhadap variabel dependen.

\section{Tes uji-t}

Uji digunakan untuk menguji pengaruh parsial gaya kepemimpinan, motivasi, dan kepuasan kerja terhadap komitmen organisasi anggota Batalyon A Brimob Mabes Sulut. Pedoman yang digunakan untuk menerima tidak menolak adalah:

1. Ha diterima jika t-hitung $>$ t-tabel atau nilai prob-nilai pada kolom sig. <tingkat signifikan $(\alpha) \quad 5 \%$ artinya variabel independen berpengaruh terhadap variabel dependen. 
2. H0 diterima jika t-hitung <t-tabel atau nilai prob-value pada kolom sig $>$ taraf signifikan $(\alpha) 5 \%$ artinya variabel tidak berpengaruh terhadap variabel dependen.

Tabel 1. Hasil uji validitas instrumen penelitian

\begin{tabular}{|c|c|c|c|}
\hline Variabel & Barang & r Korelasi & Informatian \\
\hline \multirow{2}{*}{ Gaya kepemimpinan } & X1.1 & 0,909 & \\
& X1.2 & 0,953 & Sah \\
& X1.3 & 0,912 & \\
Motivasi (X2) & X2.1 & 0.665 & \\
& X2.2 & 0.715 & \\
& X2.3 & 0.809 & Sah \\
& X2.5 & 0.828 & \\
Kepuasan Kerja (Y) & Y1.1 & 0.793 & \\
& Y1.3 & 0,672 & \\
& Y1.4 & 0.863 & Sah \\
\hline \multirow{3}{*}{ Komitmen } & Y2.1 & 0.664 & \\
Organisasi (Z) & Y2.2 & 0.656 & \\
& Y2.3 & 0.838 & \\
& Y2.4 & 0.845 & Sah \\
\hline
\end{tabular}

Sumber: Data Primer (diolah), April 2021

Dari hasil uji validitas instrumen di atas diketahui bahwa semua variabel item dalam penelitian ini dinyatakan valid dan dapat dimasukkan dalam analisis lebih lanjut. Nilai instrumen dalam penelitian ini memiliki nilai antara nilai skor dengan skor total lebih dari 0,168 .

\section{B. Uji Reliabilitas}

Uji reliabilitas yang digunakan untuk melihat apakah alat pengumpul data menunjukkan akurasi, tingkat kesulitan, gangguan, atau konsistensi dalam mengungkapkan gejala tertentu (Sugiyono 2010: 178).

Uji reliabilitas yang digunakan peneliti adalah untuk menilai konsistensi objek dan data, apakah instrumen yang digunakan beberapa kali untuk mengukur objek yang sama akan menghasilkan data yang sama. Koefisien Cronbach Alpha digunakan sebagai derajat konsistensi data. Kriteria keputusan uji reliabilitas adalah sebagai berikut:

- Jika koefisien Cronbach Alpha> 0,60 - 0-80 dikatakan reliabel

- Jika koefisien Cronbach Alpha> 0,60 - 0-80, maka sangat reliabel

Dari hasil uji reliabilitas instrumen diketahui bahwa semua variabel memiliki nilai cronbach alpha diatas 0,6 sehingga butir instrumen dinyatakan reliabel untuk digunakan dalam analisis selanjutnya. Hasil reliabilitas dalam penelitian ini disajikan pada Tabel 2. di bawah ini

Tabel 2. Hasil Uji Reliabilitas Instrumen Penelitian 


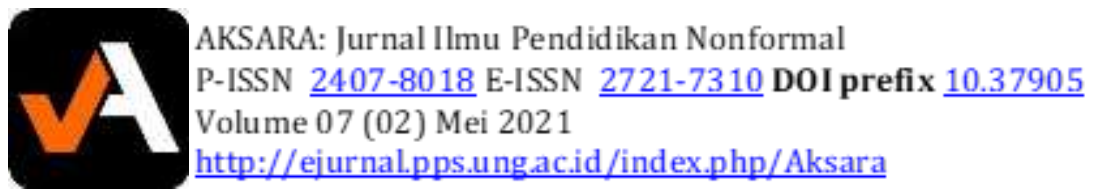

\begin{tabular}{|c|c|c|c|}
\hline Variabel & Barang & $\begin{array}{c}\text { Nilai Alpha } \\
\text { Cronbach }\end{array}$ & Informasi \\
\hline Gaya kepemimpinan & X1.1 & 0,902 & \\
(X1) & X1.2 & 0.826 & Andal \\
& X1.3 & 0,902 & \\
Motivasi (X2) & X2.1 & 0.822 & \\
& X2.3 & 0.806 & Andal \\
& X2.4 & 0.760 & \\
Kepuasan Kerja (Y) & X2.5 & 0.752 & \\
& Y1.2 & 0.766 & \\
& Y1.3 & 0.856 & \\
& Y1.4 & 0.771 & \\
& Y1.5 & 0.749 & \\
Komitmen Organisasi (Z) & Y2.1 & 0.834 & \\
& Y2.2 & 0.835 & Andal \\
& Y2.4 & 0.770 & \\
& Y2.5 & 0.767 & \\
& & 0.780 & \\
\hline
\end{tabular}

Sumber: data primer (diolah), April 2021

Dari hasil uji reliabilitas instrumen penelitian di atas diketahui bahwa semua variabel item dalam penelitian ini dinyatakan reliabel dan dapat dimasukkan dalam analisis lebih lanjut.

\section{Uji hipotesis}

Hasil penelitian ini dilakukan dengan menggunakan analisis regresi linier berganda dan analisis perhitungan menggunakan SPSS 24.0.

\section{A. Uji Regresi Linier Berganda}

Dari hasil analisis regresi linier berganda dengan menggunakan SPSS 24.0 maka hipotesis penelitian akan dibuktikan kebenarannya pada Bab IV. Hasil rekap analisis regresi linier berganda adalah sebagai berikut:

\section{Uji Determinan}

Tabel 3. Hasil Uji Determinan

Tabel Ringkasan Model Analisis Jalur Sub-Struktur 1

\begin{tabular}{|c|c|c|c|c|}
\hline Model & R & R Square & $\begin{array}{c}\text { R Square yang } \\
\text { tak terkalahkan }\end{array}$ & $\begin{array}{c}\text { Std Error dari } \\
\text { estimasi }\end{array}$ \\
\hline 1 & $0,927 \mathrm{a}$ & 0,859 & 0,857 & 0,734 \\
\hline
\end{tabular}

Sebuah. Predictors: (Constant), Motivation, Leadership Style

Dari tabel 3 di atas, analisis model jalur untuk substruktur 1 menunjukkan koefisien determinasi (R2) sebesar 0,859 yang berarti 85,9\% merupakan kontribusi variabel Gaya Kepemimpinan (X1) dan Motivasi (X2) terhadap Variabel Kepuasan Kerja (Y). Sedangkan sisanya 14,1\% mengandalkan variabel lain di luar model ini. Untuk variabel kepuasan kerja yang dapat diterapkan dengan menggunakan variabel gaya 
kepemimpinan dan motivasi sebesar $85,9 \%$. Sedangkan $14,1 \%$ sisanya disebabkan oleh variabel lain yang tidak ada dalam penelitian.

Tabel 4. Hasil Uji Determinan

Tabel Ringkasan Model Analisis Jalur Sub-Struktur 2

\begin{tabular}{|c|c|c|c|c|}
\hline Model & R & R Square & $\begin{array}{c}\text { R Square yang } \\
\text { tak terkalahkan }\end{array}$ & $\begin{array}{c}\text { Std Error dari } \\
\text { estimasi }\end{array}$ \\
\hline 1 & $0,985 \mathrm{a}$ & 0,971 & 0,970 & 0,334 \\
\hline
\end{tabular}
Motivasi

Sebuah. Predictors: (Constant), Kepuasan Kerja, Gaya Kepemimpinan,

\section{b. Variabel Terikat: Komitmen Organisasi}

Dari tabel 4 di atas, substruktur analisis jalur model 2 menunjukkan bahwa koefisien determinasi (R2) sebesar 0,971 yang berarti 97,1\% merupakan kontribusi dari Gaya Kepemimpinan (X1), Motivasi (X2) dan Kepuasan Kerja (Y) terhadap variabel Komitmen Organisasi (Z) . Sedangkan sisanya 2,9\% mengandalkan variabel lain di luar model ini. Variabel kepuasan kerja yang dapat diterapkan dengan menggunakan variabel gaya kepemimpinan dan motivasi sebesar 97,1\%. Sedangkan $2,9 \%$ sisanya disebabkan oleh variabel lain yang tidak ada dalam penelitian.

B. Tes uji-t

Uji tt digunakan untuk menguji pengaruh parsial variabel motivasi, persepsi, pembelajaran, keyakinan, dan sikap terhadap keputusan konsumen membeli koran Manado Tribune. Pedoman atau dasar pengambilan keputusan yang digunakan untuk menerima atau menolak hipotesis penelitian ini, yaitu:

- Ha diterima jika t-hitung> t-tabel atau nilai prob-nilai pada kolom sig. <tingkat signifikan $(\alpha) 5 \%$ artinya variabel independen berpengaruh terhadap variabel dependen.

- H0 diterima jika t-hitung <t-tabel atau nilai prob-value pada kolom sig> taraf signifikan $(\alpha) 5 \%$ artinya variabel tidak berpengaruh terhadap variabel dependen.

Tabel 5. Koefisien Analisis Jalur Sub Struktur Tabel 1

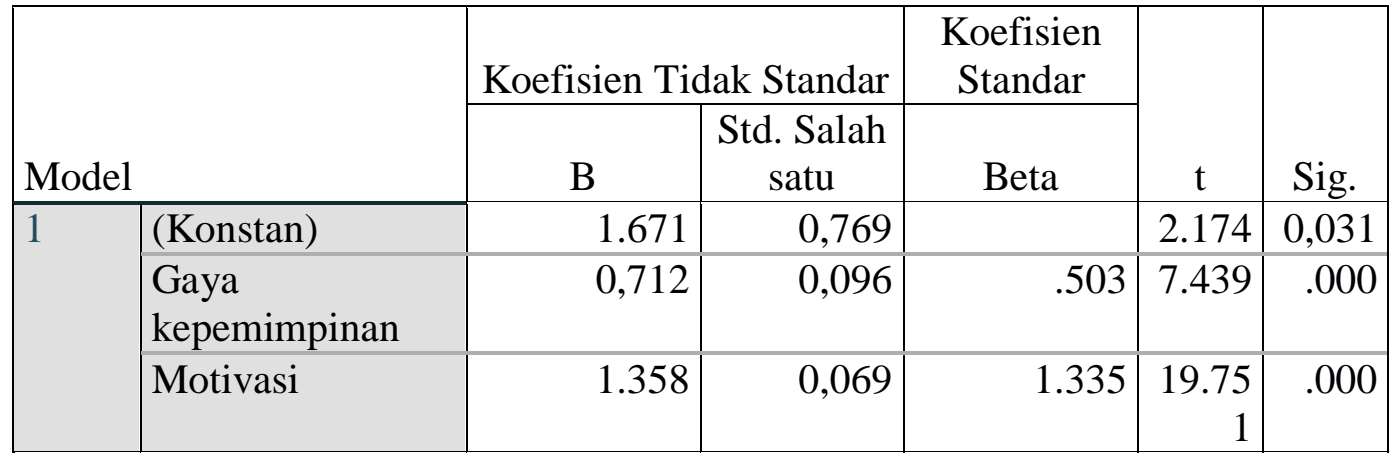

Sebuah. Variabel Dependen: Kepuasan Kerja

Berdasarkan hasil pengujian nilai t-hitung pada Koefisien Analisis Jalur Sub Struktur Tabel 1, nilai T-tabel untuk jumlah observasi adalah 136 dengan taraf alpha $(5 \%)$. dan $\mathrm{k}$ atau banyaknya semua variabel baik variabel bebas maupun variabel 
yang terkait adalah 3, maka nilai $\mathrm{T}$-tabelnya adalah $\mathrm{T}$-tabel $=\mathrm{t}(\mathrm{a} / 2 ; \mathrm{nk}-1)=\mathrm{T}$ tabel $(0,025 ; 133)=1,97796$.

Tabel 5. Koefisien Analisis Jalur Sub Struktur Tabel 2

\begin{tabular}{|c|c|c|c|c|c|c|}
\hline & & Koefisien Ti & lak Standar & $\begin{array}{c}\text { Koefisien } \\
\text { Standar }\end{array}$ & & \\
\hline & & B & $\begin{array}{l}\text { Std. Salah } \\
\text { satu }\end{array}$ & Beta & $\mathrm{t}$ & Sig. \\
\hline 1 & (Konstan) & -.345 & 0,356 & & -.970 & 0,334 \\
\hline & $\begin{array}{l}\text { Gaya } \\
\text { kepemimpinan }\end{array}$ & 0,408 & 0,052 & 0,289 & 7.886 & .000 \\
\hline & Motivasi & 0,282 & 0,062 & 0,278 & 4.550 & .000 \\
\hline & Kepuasan kerja & 0,486 & 0,039 & 0,488 & 12.327 & .000 \\
\hline
\end{tabular}

Sebuah. Variabel Terikat: Komitmen Organisasi

Berdasarkan hasil nilai t-hitung pada Tabel Koefisien Analisis Jalur Sub struktur, nilai T tabel untuk penguji adalah 136 dengan taraf alpha (5\%). dan $\mathrm{k}$ atau banyaknya semua variabel baik variabel baik variabel maupun variabel dependen adalah 4 , maka nilai T-tabelnya adalah $\mathrm{T}$ tabel $=\mathrm{t}(\mathrm{a} / 2 ; \mathrm{nk}-1)=\mathrm{T}$-tabel $(0,025 ; 132=1,97810$.

Tabel 5.21 Tabel Pengaruh Langsung, Pengaruh Tidak Langsung, dan Pengaruh Total

\begin{tabular}{|c|c|c|c|}
\hline Variabel & $\begin{array}{l}\text { Pengaruh } \\
\text { Langsung } \\
\text { Terhadap Variabel } \\
\text { Komitmen } \\
\text { Organisasi (Z) }\end{array}$ & $\begin{array}{c}\text { Pengaruh Tidak } \\
\text { Langsung Variabel } \\
\text { Komitmen } \\
\text { Organisasi (Z) }\end{array}$ & $\begin{array}{c}\text { Pengaruh Total } \\
\text { terhadap Variabel } \\
\text { Komitmen } \\
\text { Organisasi (Z) }\end{array}$ \\
\hline $\begin{array}{c}\text { Gaya } \\
\text { Kepemimpinan } \\
\text { (X1) }\end{array}$ & 0.289 & 0,245 & 0,534 \\
\hline $\begin{array}{c}\text { Motivasi (X2) } \\
\text { Kepuasan } \\
\text { Kerja (Y) }\end{array}$ & 0.278 & 0.651 & 0,929 \\
\hline
\end{tabular}

Dari hasil perhitungan tersebut, dapat dibuat detail sebagai berikut:

\section{Pengaruh Gaya Kepemimpinan terhadap Kepuasan Kerja terhadap Anggota}

\section{Batalyon A Divisi Brimob Mabes Sulut.}

Dari hasil perhitungan menggunakan SPSS 24.0 didapatkan t-hitung sebesar 7,439 dengan probabilitas (p-value) sebesar 0,000. Berikutdasar pengambilan keputusan yang digunakan untuk menerima atau menolak hipotesis, diketahui nilai T-hitung lebih besar dari pada T-tabel atau $7.439<1.97796$ atau n. Nilai probabilitas lebih signifikan dari alpha $(5 \%)$ atau 0,000>0,05. Dengan demikian, dapat diabaikan keputusan bahwa motivasi berpengaruh terhadap konsumen untuk membeli produk dari koran Manado Tribune. Hipotesis yang menyatakan bahwa "Gaya 
kepemimpinan berpengaruh terhadap komitmen organisasi anggota Batalyon A Divisi Brimob di Mabes Polri". terbukti signifikan.

2. Pengaruh Motivasi terhadap Kepuasan Kerja kepada kepada anggota Batalyon A Divisi Brimob di Mabes Polri

Dari hasil perhitungan menggunakan SPSS 24.0 didapatkan t-hitung sebesar 19,751 dengan probabilitas (p-value) sebesar 0,000. Berikutdasar pengambilan keputusan yang digunakan untuk menerima atau menolak hipotesis, nilai T-hitung lebih besar dari pada T-tabel atau $19.751<1.97796$ atau n. Nilai probabilitas ini lebih kecil dari alpha $(5 \%)$ atau $0,000>0,05$.

Sehingga dapat diabaikan bahwa persepsi berpengaruh signifikan terhadap kepuasan anggota Batalyon A Divisi Brimob di Mabes Polri. Artinya, hipotesis penelitian yang menyatakan bahwa "Ada Pengaruh Motivasi terhadap Kepuasan Kerja pada Anggota Batalyon A Divisi Brimob Mabes Sulut," adalah signifikan.

3. Pengaruh Gaya Kepemimpinan terhadap Komitmen Organisasi Anggota Batalyon A Brimob Mabes Sulut.

Dari hasil perhitungan menggunakan SPSS 24.0 didapatkan t-hitung sebesar 7.886 dengan probabilitas (p-value) sebesar 0.000. Berikutdasar pengambilan keputusan yang digunakan untuk menerima atau menolak hipotesis, nilai T-hitung lebih besar dari pada T-tabel atau4.974 $<1.97796$ atau n. Nilai probabilitas ini lebih kecil dari alpha $(5 \%)$ atau $0,000>0,05$. Dengan demikian, dapat diabaikan bahwa pembelajaran berpengaruh signifikan terhadap konsumen untuk membeli produk surat kabar Tribune Manado. Artinya, hipotesis penelitian yang menyatakan bahwa "Ada Gaya Kepemimpinan pada Komitmen Organisasi Anggota Batalyon A Divisi Brimob di Mabes Polri" terbukti signifikan.

4. Pengaruh Motivasi terhadap Komitmen Organisasi pada Anggota Batalyon A Divisi Brimob di Mabes Polri.

Dari hasil perhitungan menggunakan SPSS 24.0 didapatkan t-hitung sebesar 4,550 dengan probabilitas ( $\mathrm{p}$-value) sebesar 0,000. Berikutdasar pengambilan keputusan yang digunakan untuk menerima atau menolak hipotesis, nilai T-hitung lebih besar dari pada T-tabel atau $4.550<1.97796$ atau n. Nilai probabilitas ini lebih kecil dari alpha $(5 \%)$ atau 0,000>0,05. Dengan demikian, dapat diabaikan bahwa pembelajaran berpengaruh signifikan terhadap konsumen untuk membeli produk surat kabar Tribune Manado. Artinya, hipotesis penelitian yang menyatakan bahwa "Ada Motivasi Komitmen Organisasi pada Anggota Batalyon A Divisi Brimob di Mapolda Sulut," terbukti signifikan.

\section{Pengaruh Kepuasan Kerja terhadap Komitmen Organisasi Anggota Batalyon A} Brimob Mabes Sulut.

Dari hasil perhitungan menggunakan SPSS 24.0 didapatkan t-hitung sebesar 12.327 dengan probabilitas ( $\mathrm{p}$-value) sebesar 0.000. Berikutdasar pengambilan keputusan yang digunakan untuk menerima atau menolak hipotesis, nilai T-hitung lebih besar dari pada T-tabel atau $4.550<1.97796$ atau n. Nilai probabilitas ini lebih kecil dari alpha $(5 \%)$ atau 0,000>0,05. Dengan demikian, dapat diabaikan bahwa pembelajaran berpengaruh signifikan terhadap konsumen untuk membeli produk surat kabar Tribune Manado. Artinya, hipotesis penelitian yang menyatakan bahwa "Ada Kepuasan Kerja Terhadap Komitmen Organisasi Anggota Batalyon A Divisi Brimob di Mabes Sulut," terbukti signifikan. 
6. Pengaruh Gaya Kepemimpinan Kerja terhadap Komitmen Organisasi melalui Kepuasan Kerja pada Anggota Batalyon A Divisi Brimob Mabes Polri.

Berdasarkan hasil perhitungan tersebut, Dari perhitungan dengan menggunakan SPSS 24.0 dapat diketahui nilai t sebesar 0,0394445258. Selanjutnya nilai $\alpha=5 \%$ derajat kebebasan $=(n k-1)$ atau (136-2-1) adalah 133 sehingga $t$ tabelnya adalah 1.65639. Karena t hitung sebesar 0,0394445258 <dari t tabel 1,65639, maka kepuasan kerja tidak dapat memediasi hubungan antara gaya kepemimpinan dengan komitmen organisasi atau dengan kata lain menjadi H6 ditolak.

7. Pengaruh antara Motivasi terhadap Komitmen Organisasi melalui Kepuasan Kerja pada Anggota Batalyon A Divisi Brimob di Mabes Polri.

Berdasarkan hasil perhitungan tersebut dapat diketahui nilai $t$ sebesar 0,2232759451 . Selanjutnya nilai $\alpha=5 \%$ derajat kebebasan $=(n k-1)$ atau $(136-2-1)$ adalah 133 sehingga t tabelnya adalah 1.65639. Karena t hitung 0,2232759451 $<$ dari t tabel 1,65639, maka kepuasan kerja tidak dapat memediasi hubungan antara motivasi dengan komitmen organisasi atau dengan kata lain menjadi $\mathrm{H} 7$ ditolak.

\section{Diskusi}

Berdasarkan model penelitian yang dikembangkan dalam penelitian ini dapat merekomendasikan konsep teoritis dan memberikan dukungan empiris pada penelitian sebelumnya. Literatur yang mendeskripsikan Gaya Kepemimpinan dan Motivasi terhadap Kepuasan Kerja dengan konsep teoritis dan dukungan empiris.Mengenai hubungan kausalitas dan variabel yang mempengaruhi Kepuasan Kerja. Selanjutnya, Kepuasan Kerja akan mempengaruhi organisasi.

Kepuasan kerja akan meningkat jika gaya kepemimpinan berorientasi organisasi dalam organisasi. Hasil ini berimplikasi pada laporan bentuk gaya kepemimpinan yang kuat dalam organisasi. Indikator variabel gaya kepemimpinan seperti kepemimpinan suportif, direktif, partisipatif, dan berprestasi sangat mempengaruhi karakter gaya kepemimpinan yang kuat. Dari indikator-indikator tersebut terlihat bahwa faktor gaya kepemimpinan yang berorientasi pada prestasi bahkan dalam kondisi tidak nyaman di Batalyon Pelopor memiliki nilai yang paling rendah, karena itu organisasi harus berusaha untuk meningkatkan komitmen organisasi dengan memberikan semangat kepada para personelnya untuk selalu bekerja keras dalam. melakukan setiap pekerjaan bahkan dalam situasi sulit.

Kepuasan kerja akan meningkat jika komitmen organisasi. Hasil ini berimplikasi pada perincian motif motivasi yang sesuai dengan kondisi organisasi. Kajian terhadap indikator variabel motivasi seperti kebutuhan fisiologis, rasa aman, cinta dan kepemilikan, kebutuhan harga diri, dan kebutuhan aktualisasi diri sangat mempengaruhi komite motivasi personel dalam organisasi.

Hasil analisis menunjukkan bahwa indikator kebutuhan fisiologis di rumah sakit menunjukkan hasil. Hasil tersebut menunjukkan perubahan yang terus menerus agar suasana lingkungan kerja menjadi termotivasi, seperti mempersembahkan penghargaan secara berkelanjutan kepada personel berprestasi.

Kepuasan kerja yang meningkat akan meningkatkan komitmen organisasi. Hasil ini memiliki implikasi kepuasan kerja bagi personel. Review terhadap indikator yang menyusun variabel kepuasan kerja seperti gaji, promosi. Rekan kerja, Supervisor / Supervisor. Supervisor sangat menentukan tingkat kepuasan kerja personel dalam organisasi. Indikator promosi yang diberikan kepada personel dengan nilai paling 
rendah. Oleh karena itu, perlu terus dilakukan pembenahan dalam memberikan promosi kepada personel, misalnya dengan memberikan kesempatan mengikuti pendidikan yang membangun selektif berdasarkan senioritas, sehingga personel dapat merasakan perbedaan dalam pekerjaannya dan diharapkan organisasi akan terus berlanjut. ditingkatkan untuk setiap pribadi.

\section{PENUTUP}

Dari hasil penelitian dan pembahasan pada bab sebelumnya dapat diservis sebagai berikut:

1. Pengaruh variabel gaya kepemimpinan dan kepuasan kerja dalam penelitian ini adalah positif dan signifikan. Organisasi meningkat ketika gaya kerja meningkat.

2. Pengaruh motivasi dan kepuasan kerja positif dan tidak signifikan anggota Batalyon A Brimob Mabes Sulut.

3. Pengaruh Kepemimpinan Kerja dan Komitmen Organisasi dalam penelitian ini berpengaruh positif dan signifikan terhadap anggota Batalyon A Divisi Brimob Mabes Sulut.

4. Pengaruh motivasi dan komitmen organisasi dalam penelitian ini berpengaruh positif dan signifikan terhadap anggota Batalyon A Brimob Mabes Sulut.

5. Pengaruh kepuasan kerja dan komitmen organisasi dalam organisasi berpengaruh positif dan signifikan terhadap anggota Batalyon A Brimob Mabes Sulut.

6. Pengaruh gaya kepemimpinan terhadap komitmen organisasi dengan kepuasan kerja sebagai variabel intervening. Dalam penelitian ini variabel intervening memediasi variabel gaya kepemimpinan terhadap komitmen organisasi tidak langsung. Pengaruh gaya kepemimpinan terhadap pemaparan berpengaruh positif dan signifikan terhadap komitmen organisasi. Namun setelah melalui mediasi kepuasan kerja, pengaruh tingkat gaya kepemimpinan terhadap komitmen organisasi menurun. Hal tersebut menunjukkan bahwa variabel kepuasan kerja tidak dapat memediasi gaya kepemimpinan manajemen organisasi.

7. Pengaruh motivasi terhadap komitmen organisasi dengan kepuasan kerja sebagai variabel intervening. Pengaruh langsung variabel motivasi terhadap eksposur sebelumnya merupakan hasil yang positif dan signifikan, dan peneliti menambahkan variabel intervening untuk memediasi pengaruh positif antara motivasi dan organisasional. Hasil pengujian menunjukkan bahwa koefisien koefisien tidak berpengaruh tidak langsung menjadi negatif. Hal ini menunjukkan bahwa kepuasan kerja hanya memediasi motivasi terhadap komitmen organisasi.

\section{DAFTAR PUSTAKA}

Gibson (2006). "Organisasi (Prilaku, Struktur, Proses)," Edisi Kedua Belas, McGrow Hill. 
Gunawan.S. (2015), The Impact of Motivation, Perception, and Attitude to Consumer Purchasing Decision: A Study Case of Surabaya and Jakarta Society on Carl's Junior, iBUSS Menegement Vol.03, No, 2, March 2015

Ghozali, Imam. 2005. Aplikasi Analisis Multivariate dengan SPSS. Semarang: Badan Penerbit UNDIP. Herujito (2005). Dasar-dasar Manajemen, Penerbit PT.Grasindo.Jakarta.

Hamalik, Oemar, 2007. Manajemen Pengembangan Kurikulum, Bandung: PT. Remaja Rosda Karya.

Hair, FF, Anderson, RE, Tatham, RL dan Black, WC 1995. Analisis Data Multivariat dengan Bacaan. Prentice Hall, Engelwood Clifft, New Jersey

Hendra Indy H. Handoyo, S. 2013. Hubungan Kepuasan Kerja dengan Motivasi Kerja Pada Karyawan Bank BTPN Madiun. Jurnal Psikologi Industri dan Organisasi. Vol. 2 (2): 100-104.

L. Mathis, Robert \& H. Jackson, John. 2011. Manajemen Sumber Daya Manusia (edisi10). Jakarta: Salemba Empat.

Sugiyono. 2010. Metode Penelitian Pendidikan Pendekatan Kuantitatif, kualitatif, dan R\&D. Bandung: Alfabeta

Rhodes, L., Eisenberger, R., dan Armeli, S. 2001. Komitmen Afektif untuk Organisasi: Kontribusi Dukungan Organisasi yang Dirasakan. Jurnal Psikologi Terapan. Vol. 86. No. 5, hlm. 825-836.

Robbins, SP, dan Judge, TA 2008 a. Perilaku Organisasi. Buku 1 Edisi 12, Penerbit Salemba Empat, Jakarta.

Maartje, dan Jozef R. 2020. Pengaruh Motivasi, Kepemimpinan, dan Budaya Organisasi pada. Jurnal Keuangan Asia, Ekonomi dan Bisnis, Vol. 7 No. 8, hlm.577-588.

Setiawan, R., Pio, L., Cavaliere, L., Sankaran, D., Rani, K., Yapanto, LM, Laskar, NH, Raisal, I., Christabel, GJA, Setiawan, R., Petra, Inggris, Airlangga, U., Pio, L., Cavaliere, L., \& Foggia, U. (nd). Akses ke Layanan Keuangan dan Pemberdayaan Perempuan, melalui kelayakan Keuangan Mikro. 1, 841-859. 